\title{
A 42-year-old female presented with asymptomatic massive splenomegaly
}

\author{
Abed Hussain Khan, Esrat Khan Lubna, Mohammad Ferdous Ur Rahaman, Mahbubur Rahman, \\ Farzana Rahman and Naila Atik Khan
}

\section{Article Info \\ Department of Internal Medicine, Facul- ty of Medicine, Bangabandhu Sheikh Mujib Medical University, Shahbag, Dhaka, Bangladesh (AHK, EKL, MFUR, MR); Department of Hematology, Facul- ty of Medicine, Bangabandhu Sheikh Mujib Medical University, Shahbag, Dhaka, Bangladesh (FR); Department of Biochemistry and Molecular Biology, Faculty of Basic Science and Paraclinical Science, Bangabandhu Sheikh Mujib Medical University, Shahbag, Dhaka, Bangladesh (NAK) \\ For Correspondence: \\ Mohammad Ferdous Ur Rahaman \\ ferdousbsmmu@yahoo.com \\ Received: \\ Accepted: \\ Available Online: \\ 15 October 2019 28 November 2019 25 December 2019}

ISSN: 2224-7750 (Online) 2074-2908 (Print)

DOI: 10.3329/bsmmuj.v12i4.43523

Keywords: Hairy cell leukemia; Hemolytic anemia; Lymphoma; Spleen

Cite this article:

Khan AH, Lubna EK, Rahaman MFU, Rahman M, Rahman F, Khan NA. A 42 year-old female presented with asymptomatic massive splenomegaly. Bangabandhu Sheikh Mujib Med Univ J. 2019; 12: $211-216$

\section{Copyright:}

The copyright of this article is retained by the author(s) [Atribution CC-By 4.0]

Available at:

www.banglajol.info

\section{Presentation of Case}

Dr. Esrat Khan Lubna (MD Resident): A 42-yearold female hailing from Brahmanbaria, Bangladesh was admitted with the complaints of abdominal pain which was more marked in the left upper abdomen. Fifteen days before admission in this department, she had a history of physical assault, since then she was experiencing pain over different parts of her body including abdomen. She took analgesic for this pain. Other regional pain subsided but the abdominal pain was persisting. The abdominal pain was constant, dull aching and nonradiating. There was no aggravating or relieving factor. For the complaint of abdominal pain, she visited to a local physician. During physical examination, the consulting physician noticed splenomegaly. Then she was referred to this department for further evaluation of splenomegaly.

On examination, she was afebrile, moderately anemic and mildly icteric. Abdominal examination revealed that the spleen was $10 \mathrm{~cm}$ from the left costal margin along the anterior axillary line towards the right iliac fossa. Other systemic examination was unremarkable.

Laboratory data showed hemoglobin was low and red cell distribution width and mean corpuscular hemoglobin concentration were high on four occasions (Table I). Peripheral blood film showed normocytic normochromic anemia on three occasions. The reticulocyte count was high $(7.7 \%)$. Indirect bilirubin was slightly raised $(1.7 \mathrm{~g} / \mathrm{dL})$. Coomb's test was normal. The ultrasonography revealed splenomegaly $(17.2 \mathrm{~cm})$ (Figure 1). The endoscopy of upper gastrointestinal tract was normal. The serum IgM was normal.

\section{Provisional Diagnosis}

Hemolytic anemia

\section{Differential Diagnosis}

During discussion, the following differential diagnoses were considered. 1

\section{Hemolytic anemia}

Evaluating the features of anemia, jaundice, splenomegaly, low hemoglobin, raised reticulocytes and unconjugated hyperbilirubinemia the possibility of hemolytic anemia was the first diagnosis to be considered. Hemolytic anemia is classified as inherited and acquired.

Inherited red cell abnormalities resulting in chronic hemolytic anemia which may result from pathologies of red cell membrane. There may be membrane defects (hereditary spherocytosis, hereditary elliptocytosis), hemoglobinopathies (thalassemia, sickle cell anemia) or enzyme defect (G6PD deficiency)

Hereditary spherocytosis is a rare inherited red blood cell membrane disorder that is characterized by spherically shaped red blood cell on the peripheral blood film.24 Several reports and text books have associated a triad of anemia, jaundice, splenomegaly to the morphological findings of spherocytes as the hall mark of diagnosis..-5 It is an autosomal dominant condition which has a wide variety of presentation ranging from asymptomatic compensated chronic hemolytic state to fulminant hemolytic state. 6

Points in favor of H. spherocytosis in this patient: a) Asymptomatic massive splenomegaly, b) moderate anemia, c) mild jaundice and d) marked reticulocytosis.

Points against $H$. spherocytosis: a) Peripheral blood film- normocytic normochromic anemia and b) normal lactate dehydrogenase.

Other abnormalities of red blood cell membrane: As the incidence of hereditary elliptocytosis and G6PD deficiency is much lower in this subcontinent and in these cases patients usually have mild splenomegaly (not massive splenomegaly) and in the peripheral blood film there should be some specific features. These two diseases (hereditary elliptocytosis and G6PD deficiency) were excluded from the differential diagnoses.

\section{Hemoglobinopathies}

In thalassemia major, decreased beta chain synthesis results in excess free alpha chains, 
Table I

Laboratory investigations

\begin{tabular}{|c|c|c|c|}
\hline & $1 / 9 / 2018$ & $9 / 9 / 2018$ & References \\
\hline Hemoglobin (g/dL) & 9.3 & 9.0 & $15 \pm 2$ (male); $13.5 \pm 1.3$ (female) \\
\hline Erythrocyte sedimentation rate ( $\mathrm{mm}$ in $1^{\text {st }}$ hour) & 20 & 05 & $0-10$ \\
\hline Total white blood cells $\left(\times 10^{9} / \mathrm{L}\right)$ & 6.5 & 4.5 & $7 \pm 3$ \\
\hline Total platelet count $\left(\times 10^{9} / \mathrm{L}\right)$ & 180 & 150 & $150-400$ \\
\hline Total red blood cells $\left(\times 10^{12} / \mathrm{L}\right)$ & 6.0 & 3.1 & $5 \pm 0.5$ (male) $; 4.3 \pm 0.5$ (female) \\
\hline Neutrophils (\%) & 57 & 61 & $50-70$ \\
\hline Lymphocytes (\%) & 35 & 31 & $20-40$ \\
\hline Mean corpuscular volume (fL) & 85 & 85 & $92 \pm 9$ \\
\hline Mean corpuscular hemoglobin (pg) & 29 & 29 & $29.5 \pm 0.5$ \\
\hline Mean corpuscular hemoglobin concentration $(\mathrm{g} / \mathrm{dL})$ & 36 & 34 & $33 \pm 1.5$ \\
\hline Red cell distribution width (\%) & 23 & 24 & $12.8 \pm 1.2$ \\
\hline Serum bilirubin (total) (mg/dL) & 2.1 & & $0.2-1.2$ \\
\hline Serum bilirubin (direct) $(\mathrm{mg} / \mathrm{dL})$ & 0.4 & & $<0.3$ \\
\hline Lactate dehydrogenase (IU/L) & 142 & & $208-378$ \\
\hline Reticulocyte count (\%) & 7.7 & & $<2$ \\
\hline Coombs' test (direct and indirect) & Negative & & \\
\hline Serum immunoglobulin M level (mg/dL) & 98 & & $40-230$ \\
\hline
\end{tabular}

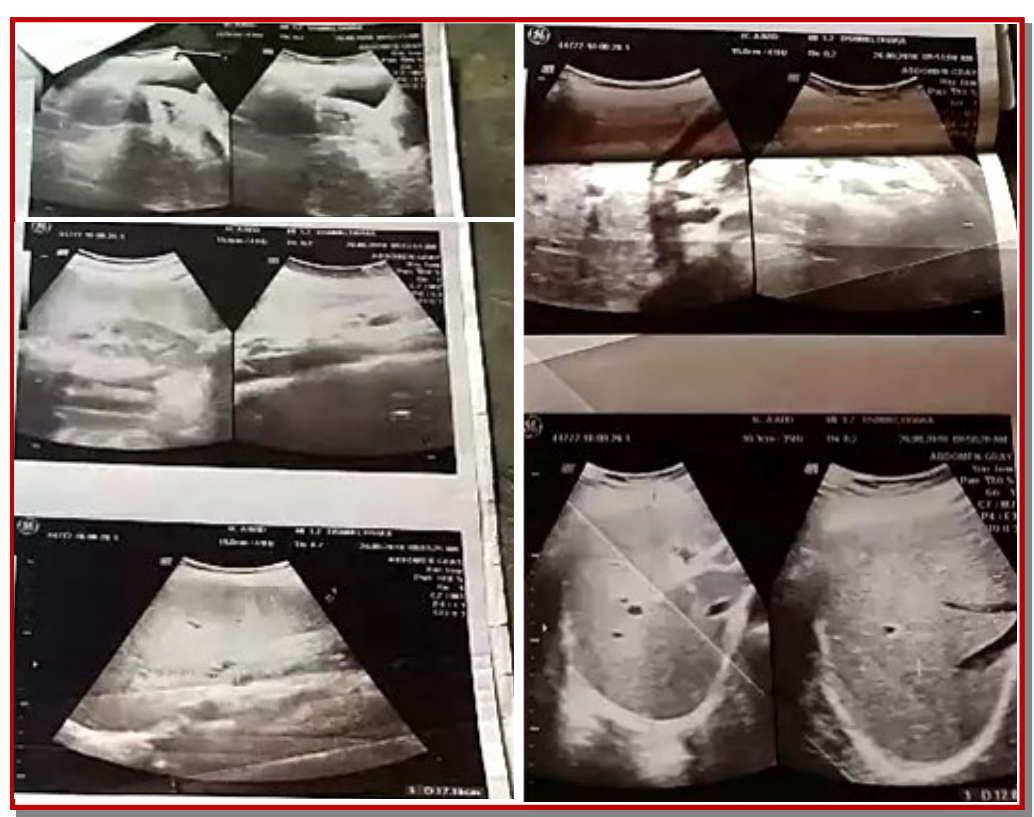

Figure 1: Ultrasonography of whole abdomen

resulting in elevated hemoglobin $\mathrm{F}$ or hemoglobin A 2. 7 Free alpha chains also form insoluble tetramers that precipitate within the red blood cell causing increased fragility and cell death. $\underline{\text { Patients of beta- }}$ thalassemia often present as severe microcytic anemia with signs of cardiac dysfunction, pallor, jaundice, hepatosplenomegaly and growth failure. 9

In beta-thalassemia minor, patients have mild ane- mia, microcytic hypochromic anemia, target cells and raised hemoglobin $\mathrm{A}_{2}$ fraction.

Sickle cell anemia is a hemoglobin disorder resulting from the inheritance of the sickle beta globin gene. The patient may present with vaso-occlusive crisis. Visceral sequestration crisis which is caused by sickling within organs. splenic sequestration is typically seen in infants and presents with enlarging spleen and falling hemoglobin. There may be aplastic crisis or hemolytic crisis. 10

In this case (asymptomatic splenomegaly having moderate anemia with mild jaundice), hemoglobinopathies like thalassemia could be a good possibility. However, hemoglobinopathies with huge splenomegaly patients should have previous history of blood transfusion which was absent in this case. Moreover, there was no microcytic hypochromic anemia in peripheral blood film and no target cell or sickle cell as well. Hemoglobin electrophoresis was also normal. So, hemoglobinopathies (thalassemia, sickle cell anemia) were also excluded as well from the differential diagnosis.

\section{Acquired hemolytic anemia}

Acquired hemolytic anemia causes include auto and alloantibody-mediated destruction of red blood cells and other mechanical, toxic and infective causes. 11

\section{Autoimmune hemolytic anemia}

Considering the clinical features and some investi- 
gations, the autoimmune hemolytic anemia was one of the possibilities. Points in favor of autoimmune hemolytic anemia: a) splenomegaly, b) middle aged female and c) features of hemolysis.

Points against: a) Coombs' test was negative, b) nucleated red blood cell and spherocytes were absent in the peripheral blood film and c) no history of significant drug intake or features of systemic lupus erythematosus, rheumatoid arthritis or any infection.

\section{Hairy cell leukemia}

Hairy cell leukemia is an uncommon chronic betacell lymphoproliferative disease. The median age of presentation is approximately 55 years, with a male predominance of $4: 1.12$ Symptoms include abdominal fullness, fatigue, weakness, weight loss and bruising. Approximately a quarter of patients present with abdominal discomfort and fullness due to splenomegaly which can be massive. In a study of 71 cases of hairy cell leukemia, $5 \%$ of patients had a spleen tip that was $20 \mathrm{~cm}$ below the left costal margin. 13 The peripheral blood film shows hairy like cytoplasmic projection. Marrow biopsy shows diffuse, focal or interstitial infiltration of hairy cells. $\underline{14}$ It has been reported that patients with hairy cell leukemia having massive splenomegaly may stay asymptomatic for a significant period. In adverse condition, the patient may develop symptoms. $\underline{15}$

Points against hairy cell leukemia in this case: a) There was no hairy appearance of white blood cells in the peripheral blood film, b) there was no pancytopenia or bicytopenia and c) no history of fever, easy bruising and no infection.

\section{Splenic lymphoma}

Splenic marginal zone lymphoma can present only with splenomegaly without lymph node involvement. It is relatively indolent beta-cell lymphoma that results from proliferation of small lymphocytes that surround and replace the splenic white and red pulp. $\underline{16}$ The hallmark of clinical presentation is massive splenomegaly. In a group of over 300 patients with non-Hodgkin's lymphoma, splenic marginal zone lymphoma was found in 81 patients, accounting for $2.7 \%$ of all lymphoma. 17 The hallmark of clinical presentation is massive splenomegaly. The patient may not have other symptoms of lymphoma except slight heaviness in the left upper abdomen. Patient may have anemia, lymphocytosis and thrombocytopenia. $\underline{18}$ Specific peripheral blood film findings (villous lymphocytes) may also be found. 19

Points against the disease in this patient are: a) Complete blood count - only low hemoglobin\% but no leukopenia or thrombocytopenia, b) red cell distribution width was increased, c) marked reticulocytosis, d) peripheral blood film showed no specific comment about lymphocytosis.

\section{Chronic liver disease with portal hypertension}

Massive splenomegaly is one of the important causes of chronic liver disease with portal hypertension. But in this patient, there was no other feature of chronic liver disease with portal hypertension. Moreover, the ultrasonography of the liver architecture is normal. But non-cirrhotic portal hypertension could be a possibility.20 In non-cirrhotic portal hypertension, lesion is generally vascular, present in the portal vein, or its branches in the perisinusoidal area of the liver. It is a disease of young to middle age. 21 In non-cirrhotic portal hypertension duration of symptoms at presentation varies from 15 days to 18 years. 22 Hypersplenism may remain asymptomatic. Bleeding from the non-gastrointestinal sites is reported to be about $20 \% . \underline{23}$ Ascites develops in 10-34\% patients of non-cirrhotic portal hypertension. Esophageal varices are seen in 80-90\% patients. $\underline{24}$

Points in favor of non-cirrhotic portal hypertension in the patient were: a) massive splenomegaly, b) Peripheral blood film showed normocytic normochromic anemia, c) asymptomatic state of the patient, d) no ascites, jaundice, encephalopathy during early stage but may develop in later stages, e) test results indicated normal or near normal liver function, and $f$ ) absence of signs of chronic liver disease.

Points against are: a) there was no history of hematemesis and melena and b) in endoscopy- no esophageal varix or congestive gastropathy.

\section{Tropical splenomegaly syndrome}

Malaria can frequently cause splenomegaly but massive is rare. Hyperreactive malarial splenomegaly is a complication of malaria that can cause chronic massive splenomegaly. The syndrome has features of fever, anemia, pancytopenia, weight loss, abdominal discomfort, lassitude. $\underline{25}$ In this patient, she did not have any history of residing in malaria endemic zone and her serum IgM level was normal. So, this was unlikely. $\underline{26}$

\section{Adult Gaucher's disease}

Gaucher's disease is an autosomal recessive lysosomal glycolipid storage disorder. Deficiency of beta glycosidase causes accumulation of glucosylcerramide in macrophages leading to hepatosplenomegaly, anemia, thrombocytopenia and bone disease. Bone manifestations include fractures, bone infarction and vertebral collapse. 27 There may also be neurological involvement. 28

Splenomegaly is one of the presenting signs. $\underline{29}$ It is rare condition involving approximately 1 in 50,000100,000 in the general population. 30 This patient did not have any family history of Gaucher's disease or known carrier state. There was no history of osteoporosis, spontaneous bone fracture, arthritis, easy bruising and investigations revealed no thrombo- 
cytopenia. So, this was excluded from differential diagnosis.

\section{Myelofibrosis}

Myelofibrosis can affect patients in various ways including progressive splenomegaly, cytopenias (particularly anemia), constitutional symptoms (night sweats, fever, unintentional weight loss, fatigue). $\underline{31}$ It can also result in blastic transformation and death. $.32,33$ Splenomegaly can be a major independent source of morbidity and detrimental to the quality of life when it develops in patients with myelofibrosis. $\underline{34,35}$ This patient didn't have any symptom like lassitude, weight loss and night sweats. Peripheral blood film didn't reveal leukoerythroblastic blood picture. So, this was at the bottom of the differentials.

At last bone marrow examination was planned but prior to the bone marrow examination, physical examination findings were considered again and as there were features of hemolysis in hematological investigations. Peripheral blood film was repeated again with special attention to any abnormal red blood cell. This time peripheral blood film report revealed frequent spherocytes (Figure 2). Then Coomb's test and osmotic fragility test were done. Coomb's test was negative but osmotic fragility was markedly increased.

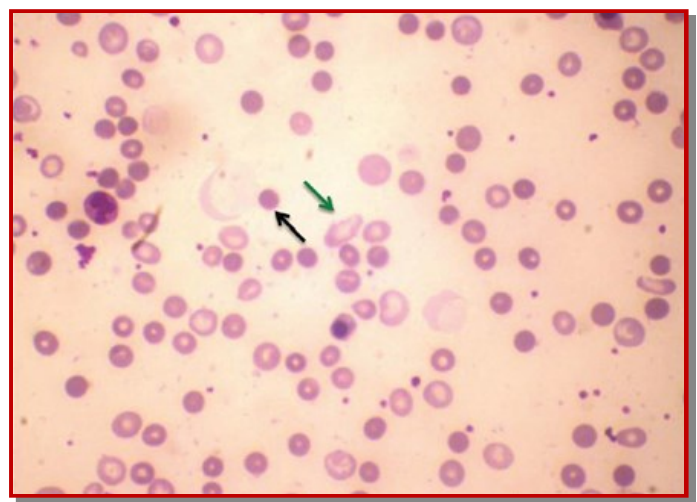

Figure 2: Peripheral blood film showing spherocyte (black colored arrow), elongated cell (green colored arrow)

After dealing with the patient there is a lesson learnt that clinical diagnosis is the most important tool for the clinicians. Diagnosis should not be solely dependent upon lab investigations. Rather this simple investigation should be repeated, if there is a strong suspicion for a particular clinical diagnosis.

\section{Dr. Lubna's Diagnosis}

Hereditary spherocytosis

\section{Discussion}

Dr. Bristi (MD Resident): Why it is called mild hereditary spherocytosis?

Dr. Lubna: Mild hereditary spherocytosis is called because the patient was asymptomatic before the event of physical assault. Literature review showed that $20-30 \%$ cases can be asymptomatic or mildly anaemic with or without having mild splenomegaly. However, they may develop hemolytic or aplastic episode triggered by infections or other stressful conditions.$\underline{36}$

Dr. Sania (MD Resident): What is the main pathophysiology of hereditary spherocytosis?

Dr. Lubna: It's a familial hemolytic disorder associated with a variety of mutations that lead to defects in red blood cell membrane proteins.

Four abnormalities in red blood cell membrane were a) spectrin deficiency alone, b) combined spectrin and ankyrin deficiency, c) band 3 deficiency and d) protein 4.2 defects.. $\frac{37,38}{}$

Due to defects in red blood cell membrane when the red blood cells pass through splenic microcirculation they become spherical in shape and lose their membrane.

Dr. Ashad (MD Resident): What are the complications of hereditary spherocytosis?

Dr. Lubna: There may be as follows: a) cholelithiasis occurs due to chronic hemolysis, b) aplastic crisisoccurs due to parvovirus B19 infection, c) hemolytic crisis occurs due to intercurrent infection and $d$ ) megaloblastic crisis occurs due to folic acid deficiency.

Dr. Hema (MD Resident): What are the confirmatory tests of hereditary spherocytosis?

Dr. Lubna: After getting spherocytes in peripheral blood film, this can do osmotic fragility test (sensitivity $68 \%$, specificity $81 \%$ ) Another test named Eosin 5 maleimide binding test can be done. It is reduced in hereditary spherocytosis (sensitivity $93 \%$, specificity $98 \%$ ). But this test is not available in this country. $\cdot \underline{39}$

Dr. Imam (MD Resident): What will be the treatment options for this patient?

Dr. Lubna: As the patient does not have any pressure symptoms or any clinical feature of complications like severe anemia or gallstone, this will give only folic acid supplementation and follow up the patient in regular interval. In future if there is development of any complication or crisis, then this will plan for splenectomy according to the risk benefit ratio. $\underline{40}$

Dr. Shadly (Resident): What are the risks of splenectomy and what precautions should be taken? 
Dr. Lubna: There is a risk of infection by encapsulated bacteria after splenectomy. Before splenectomy, this should vaccinate the patient with Pneumococcal (5 yearly) Meningococcal and Influenzae (yearly) vaccine.

Dr. Afrina (MD Resident): Why peripheral blood film was normal in the first three occasions?

Dr. Lubna: Spherocytes can be absent in peripheral blood film due to technical errors or rarely if the patient is in carrier state. 6 In this patient, it was possibly due to technical error as the fourth peripheral blood film showed spherocytes.

Dr. Atiq (MD Resident): What is the prognosis of the disease?

Dr. Lubna: Information about life expectancy in the medical literature appears to be limited. Prognosis depends on the severity of the condition in each person.

\section{Final Diagnosis}

Hereditary spherocytosis

\section{Conflict of Interest}

Authors declare no conflict of interest.

\section{References}

1. Pozo AL, Godfrey EM, Bowles KM. Blood reviews splenomegaly: Investigation, diagnosis and management. Blood Rev. 2009; 23: 105-11.

2. Hoffbrand $\mathrm{AV}$, Moss PAH. Essential haematology $6^{\text {th }}$ ed. Oxford, Wiley Blackwell, 2011, pp 60-63,78 79.

3. Gallager PG, Forget BG. Hereditary Spherocytosis, elliptocytosis and related disorders. In: Williams Haematology. $6^{\text {th }}$ ed. Chicago, McGraw Hill, 2000, pp 1189-209.

4. Shafqat S, Roger V. Hereditary spherocytosis. Paediatr Rev. 2001; 25: 168-72.

5. Hassoun H, Palek J. Hereditary spherocytosis: A review of clinical and molecular aspects of the disease. Blood Rev. 1996; 10: 129-47.

6. Bolton-maggs PHB, Langer JC, Iolascon A, Tittensor $\mathrm{P}$, King MJ. Guidelines for the diagnosis and management of hereditary spherocytosis- 2011 update. Br J Haematol. 2012; 156: 37-49.

7. Rund D, Rachmilewitz E. Beta thalassemia. N Engl J Med. 2005; 353: 1135-46.

8. Borgna-Pignatti C, Cappellini MD, De Stefano $\mathrm{P}$ Del Vecchio GC, Forni GL, Gamberini MR, Ghilardi
R, Origa R, Piga A, Romeo MA, Zhao H, Cnaan A. Survival and complications in thalassemia. Ann N Y Acad Sci. 2005; 1054: 40-47.

9. Vento S, Cainelli F, Cesario F. Infections and thalassemia. Lancet Infect Dis. 2006; 6: 226-33.

10. Moll S, Orringer EP. Splenomegaly and splenic sequestrations in adults with sickle cell anemia: A case report. Am J Med Sci. 1996; 312: 299-302.

11. Packman $\mathrm{CH}$. The clinical pictures of autoimmune hemolytic anemia. Transfus Med Hemother. 2015; 42: $317-24$

12. Hoffman MA. Clinical presentations and complications of hairy cell leukemia. Haematol Oncol Clin. North Am. 2006; 20: 1065-73.

13. Golomb HM, Catovsky D, Golde DW. Hairy cell leukemia: A clinical review based on 71 cases. Ann Intern Med. 1978; 89: 677-83.

14. Ravandi F, O'Brien S. Chronic lymphoid leuke-mias other than chronic lymphocytic leukemia: Diagnosis and treatment. Mayo Clin Proc. 2005; 80: 1660-74.

15. Venkatesan S, Purohit A, Aggarwal M, Manivannan P, Tyagi S, Mahapatra M, Pati HP, Saxena R. Unusual presentation of hairy cell leukemia : A case series of four clinically unsuspected cases. Indian J Haematol Blood Transfus. 2014; 30: 413-17.

16. Thieblemont C, Felman P, Callet-Bauchu E, Traverse-Glehen A, Salles G, Berger F, Coiffier B. Splenic marginal zone lymphoma: A distinct clinical and pathological entity. Lancet Oncol. 2003; 4: 95103

17. Thieblemont C, Felman P, Berger F, Dumontet C, Arnaud P, Hequet O, Arcache J, Callet-Bauchu E, Salles G, Coiffier B. Treatment of patients with splenic marginal zone B-cell lymphoma: An analysis of 81 patients. Clin Lymphoma. 2002; 3: 41-47.

18. Djokic M, Plesnik B, Petric M, Trotovsek B. Massive splenomegaly due to B-cell lymphoma. Int J Surg Case Rep. 2018; 48: 76-78.

19. Parry-Jones N, Matutes E, Gruszka-Westwood AM, Swansbury GJ, Wotherspoon AC, Catovsky D. Prognostic features of splenic lymphoma with villous lymphocytes: A report on 129 patients. Br J Haematol. 2003; 120: 759-64.

20. Sarin SK, Khanna R. Non-cirrohotic portal hypertension. Clin Liver Dis. 2014; 18: 451-76.

21. Bosch J, Mastai R, Kravetz D, Navasa M, Rodes J. Haemodynamic evaluation of the patient with portal hypertension. Semin Liver Dis. 1986; 6: 30917.

22. Vakili C, Farahhavsh MJ, Bynum TE. Endemic idiopathic portal hypertension: Report on 32 patients with non-cirrhotic portal fibrosis. World J Surg. 1992; 16: 118-25.

23. Sama SK, Bhargava S, Nath NG, Talwar JR, Nayak NC, Tandon BN, Wig KL. Non-cirrhotic portal 
fibrosis. Am J Med. 1971; 51: 160-69.

24. Qureshi H, Kamal S, Khan RA, Zuberi SJ, Alam SE. Differentiation of cirrhotic vs idiopathic portal hypertension using 99m Tc-Sn colloid dynamic and static scintigraphy. J Pakistan Med Assoc. 1991; 41: 126-29.

25. Vinetz JM, Li J, McCutchan TF, Kaslow DC. Plasmodium malariae infection in an asymptomatic 74-year-old Greek woman with splenomegaly. N Engl J Med. 1998; 338: 367-71.

26. Leoni S, Buonfrate D, Angheben A, Gobbi F, Bisoffi $Z$. The hyper-reactive malarial splenome-galy: A systematic review of the literature. Malar J. 2015; 14: 185.

27. Beutler E. Gaucher's disease: Multiple lessons from a single gene disorder. Acta Paediatr. 2006; 95: 10309.

28. Weinreb NJ, Aggio MC, Andersson HC, Andria G, Charrow J, Clarke JT, Erikson A, Giraldo P, Goldblatt J, Hollak C, Ida H, Kaplan P, Kolodny EH, Mistry P, Pastores GM, Pires R, Prakash-Cheng A, Rosenbloom BE, Scott CR, Sobreira E, TylkiSzymańska A, Vellodi A, vom Dahl S, Wappner RS, Zimran A. International Collaborative Gauchers Group (ICGG). Gauchers disease type 1: Revised recommendations on evaluation and monitoring for adult patient. Semin Haematol. 2004; 41: 15-22.

29. Pastores GM, Weinreb NJ, Aerts H, Andria G, Cox TM, Giralt M, et al. Therapeutic goals in the treatment of Gauchers disease. Semin Haematol. 2004; 41 (Suppl): 4-14.

30. Singla S, Ninama R, Jain B, Goyal S. Gaucher's disease: A case report. Int J Res Med Sci. 2017; 4: 1712-14.

31. Mesa RA, Niblack J, Wadleigh M, Verstovsek S, Camoriano J, Barnes S, Tan AD, Atherton PJ, Sloan JA, Tefferi A. The burden of fatigue and quality of life in myeloproliferative disorders: An international internet based survey of 1179 myeloproliferative disorder patients. Cancer 2007; 109: 6876.

32. Mesa RA, Li CY, Ketterling RP, Schroeder GS, Knudson RA, Tefferi A. Leukemic transforma- tion in myelofibrosis with myeloid metaplasis: A single institution experience with 91 cases. Blood 2005; 105: 973-77.

33. Cervantes F, Dupriez B, Pereira A, Passamonti F, Reilly JT, Morra E, Vannucchi AM, Mesa RA, Demory JL, Barosi G, Rumi E. A new prognostic scoring system for primary myelofibrosis based on a study of the international working group for myelofibrosis research and treatment. Blood 2008; 112: 657-70.

34. Reilly JT. Idiopathic myelofibrosis: Pathogenesis, natural history and management. Blood Rev. 1997; 11: 233-42.

35. Koch CA, Li CY, Mesa RA, Tefferi A. Nonhepatosplenic extramedullary haematopoesis: Associated diseases, pathology, clinical courses and treat-ment. Mayo Clin Proc. 2003; 78: 1223-33.

36. Chandra R, Gupta M, Chauhan G, Mahavar S. Hereditary spherocytosis in a 17 year girl: A case report. IMJH. 2017; 3: 226-29.

37. Delaunay J. The molecular basis of hereditary red cell membrane disorders. Blood Rev. 2007; 21: 1-20.

38. Perrotta S, Gallagher PG, Mohandas N. Heredi-tary spherocytosis. Lancet 2008; 372: 1411-26.

39. Bianchi P, Fermo E, Vercellati C, Marcello AP, Porretti L, Cortelezzi A, Barcellini W, Zanella A. Diagnostic power of laboratory tests for hereditary spherocytosis: A comparison study in 150 patients grouped according to molecular and clinical characteristics. Haematologica 2012; 97: 51623.

40. Bolton-Maggs PH, Stevens RF, Dodd NJ, Lamont G, Tittensor P, King MJ, General Haematology Task Force of the British Committee for Standards in Haematology. Guidelines for the diagnosis and management of hereditary spherocytosis. $\mathrm{Br} \mathrm{J}$ Haematol. 2004; 126: 455-74.

41. Marchetti M, Quaglini S, Barosi G. Prophylactic splenectomy and cholecystectomy in mild hereditary spherocytosis: Analyzing the decision in different clinical scenerios. J Intern Med. 1998; 244: 217-26. 